\title{
Urban Flash Floods Mitigations: Enhancing the Link between Water, Sanitation and Energy Services in Urban Settings in the MENA Region
}

ISSN: 2639-0574

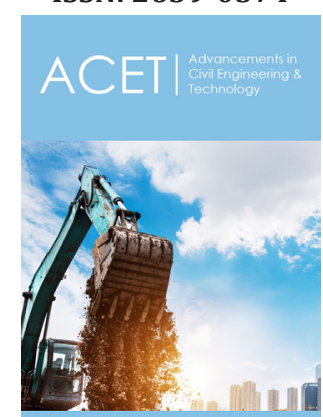

${ }^{* 1}$ Corresponding author: Amgad Elmahdi, Head of MENA Region The International Water Management Institute (IWMI), Egypt, Email: A.Elmahdi@cgiar.org

Submission: 監April 01, 2020

Published: April 06, 2020

Volume 4 - Issue 2

How to cite this article: Mohamed Tawfik, Adham Badawy, Marwa Ali, Nafn Amdar, Amgad Elmahdi. Urban Flash Floods Mitigations: Enhancing the Link between Water, Sanitation and Energy Services in Urban Settings in the Mena Region. Adv Civil Eng Tech. 4(2). ACET.000582. 2020.

DOI: $10.31031 /$ ACET.2020.04.000582

Copyright@ Amgad Elmahdi, This article is distributed under the terms of the Creative Commons Attribution 4.0 International License, which permits unrestricted use and redistribution provided that the original author and source are credited.

\author{
Mohamed Tawfik ${ }^{1,2}$, Adham Badawy², Marwa Ali $^{2}$, Nafn Amdar ${ }^{2}$ and Amgad \\ Elmahdi ${ }^{2 *}$ \\ ${ }^{1}$ Wageningen University and Research, Netherlands \\ ${ }^{2}$ The International Water Management Institute (IWMI), Egypt
}

\section{Climate Change Impacts and Water Services}

For centuries, the control and delivery of water has shaped states and economies across the Middle East and North Africa (MENA) region. In the 20th century, key infrastructure development tamed key river systems for water supply and led to huge expansion in irrigation, as population nearly quadrupled. More recently, MENA has experienced severe water stress against a background of recurring droughts and worsening environmental degradation, rapid urbanization and persistent food insecurity, compounded by conflict and civil unrest, giving rise to mass migration [1]. It is important to distinguish between water services availability, accessibility and quality. According to the Manual on the Human Rights to safe drinking water and sanitation for practitioners, water supply availability refers to the reliable quantity of water supply, while accessibility refers to the 'time and distance' needed to get access to the water supply. While water services might be available, it does not necessarily mean that they are accessible, as water could be available in terms of quantity but of poor quality that makes it also inaccessible. Additionally, climate change is projected to have serious implications on water resources and services. According to the Intergovernmental Panel on Climate Change (IPCC) report in 2014, it is expected that extreme weather events such as droughts, floods, and flash floods will increase in both frequency and intensity under a projected warmer atmosphere [2]. This will add more challenges to the existing and established services infrastructure. In arid regions, most of the infrastructures are not designed to handle such extreme events in particular heavy and intense rain events. Where infrastructure is not often designed on extreme events with long return period in order not to raise the cost of construction and hinder the development process, especially in developing countries [2].

In case of floods and flash floods in urban settings, the damage to the water services infrastructure might impair the quality, availability and accessibility to drinking water supply and sanitation services. This is more critical in densely populated urban settings, where the sewerage network exceeds its full capacity and there is no proper storm water network. This is particularly visible in arid developing countries such as the Middle East and North Africa (MENA) region, which are not prepared to handle extreme weather events and often suffer from worn-out water and sanitation services network.

\section{Flash Floods Mitigations in Urban Setting}

There are various mitigation measures adopted globally to mitigate flooding in cities. This will be discussed globally and in context to the Middle East and North Africa (MENA) region where flooding events are starting to become more frequent, and countries are developing different mitigation measures based on the contextual constraint(s) of that country. Arid and semi-arid regions are known for being water scarce (either in availability or sufficient infrastructure) and the impact of climate change is more sensible in these areas-an example of climate change impact is the flash flood. Accordingly, countries in the MENA region such as Egypt, Jordan and Saudi Arabia have struggled for so long -and still- to address their water scarcity challenges. The shifts in rainfall patterns to more frequent high intensity- 
short duration storms, with the urban expansion, has prompted those countries to look for solutions that are applied worldwide to mitigate urban flooding. The following table explores different flood mitigation measures that are applied in different contexts. It was the turn of the MENA countries to choose, modify and adapt one -or more- of these options.

\section{Urban-Flooding and the Feasibility Challenges}

Investing in storm water network might be unfeasible for countries in the arid and semi-arid region due to the scarce to low precipitation rate. However, during the last decades, these regions started to receive extreme storms that lead to flash floods events associated with climate change. Which their quantities exceed the capacity of the existing infrastructure. Although most of the grey infrastructure measures explored in Table 1 would add a financial burden on those countries, they do receive more fund than green infrastructure [3]. Recently a growing number of developed and developing countries are ditching their hard infrastructure in order to incorporate more Nature-Based Solutions (NBS) as they are more viable on the long run and more sustainable (ibid). Without doubt, there are a number of associated challenges including uncertainty with climate change, challenges the financial, technological, infrastructural and management abilities of developing countries. However, the biggest challenge is the ability to adopt an inclusive governance system that coordinates the different actors (public and private) in order to be agile and adopt efficient solutions such as NBS. Therefore, adopting a resilient governance system will subsequently reflect on the resilience capabilities of water and sanitation services [4].

Table 1: Urban flooding mitigation measures and mechanisms (Source: wavin.com).

\begin{tabular}{|c|c|c|}
\hline Mitigation Measure & Category & Mitigation Mechanism \\
\hline $\begin{array}{l}\text { Stormwater drainage } \\
\text { networks }\end{array}$ & Conventional grey infrastructure. & $\begin{array}{l}\text { Stormwater drainage networks collect and drain stormwater away from the sewer } \\
\text { network, then discharge it to a water body (e.g. river, lake, sea) }\end{array}$ \\
\hline $\begin{array}{l}\text { Sewer network flood } \\
\text { drainage }\end{array}$ & Conventional grey infrastructure. & $\begin{array}{l}\text { Prepare the sewer network to receive the stormwater flow, by increasing its capacity } \\
\text { and with adequate solid waste management to prevent its clog-gage. }\end{array}$ \\
\hline $\begin{array}{l}\text { Flood early warning } \\
\text { systems }\end{array}$ & ICT based mitigation measure & $\begin{array}{l}\text { With available climate data and forecasting, climatologists can provide reliable data to } \\
\text { decision-makers who can issue flood warnings. }\end{array}$ \\
\hline Green rooftops & $\begin{array}{l}\text { Sustainable Urban Drainage } \\
\text { system (SUDs) }\end{array}$ & $\begin{array}{l}\text { Green rooftops might be seen as a complementary mitigation measure that helps with } \\
\text { reducing the quantity of urban run-off. }\end{array}$ \\
\hline $\begin{array}{l}\text { Permeable surfaces } \\
\text { (e.g. pavements and } \\
\quad \text { sidewalks) }\end{array}$ & $\begin{array}{l}\text { Sustainable Urban Drainage } \\
\text { system (SDUs) }\end{array}$ & $\begin{array}{l}\text { Grey infrastructure and drainage networks cannot accommodate the large volumes } \\
\text { of stormwater, thus overflow. While permeable surfaces provide the opportunity to } \\
\text { absorb stormwater and recharge groundwater aquifers. }\end{array}$ \\
\hline 'Sponge' cities & $\begin{array}{l}\text { Sustainable Urban Drainage } \\
\text { system (SDUs) }\end{array}$ & $\begin{array}{l}\text { Lead by many Chinese cities in order to shift from grey infrastructure and reuse } \\
\text { stormwater within the boundaries of the city for different purposes. }\end{array}$ \\
\hline
\end{tabular}

Although, this shift in governance modes seems logical, many developing countries prefer to rely on conventional technical solutions such as reducing the loads on their sewerage network capacity to take in the flooding amount, through water supply interruption in the urban settings. Choosing this option might cost the country to risk water services' availability, accessibility and quality during the flooding event and throughout the recovery period. These risks are illustrated in the form of a 'nexus' Figure 1, where water, energy, and sanitation services are interdependent; as water quality, availability, and accessibility are interdependent.

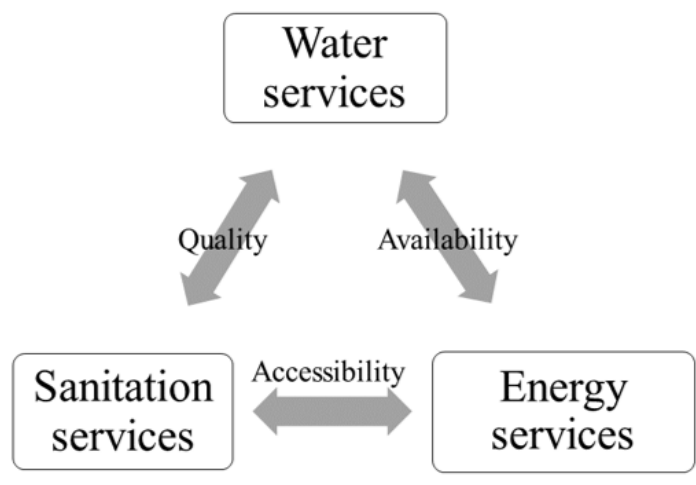

Figure 1: Water, sanitation and energy nexus.

\section{Cases from the MENA Region}

\section{Cairo}

Egypt recently experienced an extreme event of urban flooding. Cairo is a mega city in an arid region, with a population over 15 million and a scarce rainfall. The city depends on its sewerage network to absorb the urban runoff. The sewerage network that struggle to provide coverage to all Cairenes throughout its history [5], withstand considerable pressure to accommodate the unprecedented rainfall events, which became more frequent in the 
last few years. Accordingly, the Egyptian government took serious mitigation measures that can be applied with the current economic constraints. This mitigation based on the full coordination between the Ministry of Water Resources and Irrigation (MWRI) and The Holding Company for Water and Wastewater (HCWW) [6] and others government public agencies.

The MWRI started by lowering water levels in the irrigation canals and drains across the Nile Delta and valley to avoid over flooding from the heavy rainfall. Simultaneously, MWRI increased the maintenance effort to keep the main streams of the active wadies clear to discharge flooding water directly to the River Nile. At the same time, the HCWW cut off water supply from high risk districts. That was one way to reduce Cairenes water consumption, thus alleviate the pressure on the sewerage network. Additionally, fleets of vacuum trucks have been distributed across Cairo streets with high risk of flooding. These mitigation measures succeeded to mitigate flash flooding impacts on Cairo in a faster time interval than previous years. However, it caused prolonged periods of water services interruption. Additionally, electricity services have been cut off from several areas around the city where water accumulated and posed electric shock risk to passersby and residents. The interruption of electricity caused the interruption of water pumping stations in the water treatment plants prior to distribution [7], which prolongs water services interruption for citizens. Additionally, the electricity services interruption added a burden on Cairenes who are mostly dependent on private pumps to produce suction pressure to deliver water to households living on high floors. The post-event revealed that there was high sediment in the mainstream of the river Nile, which was flushed from wadies, beds due to the high velocity of the runoff. Subsequently, some water treatment plants were forced to reduce their treatment capacity as the sediment rate exceeded the threshold of their ability to treat.

\section{Riyadh}

Saudi Arabia's cities of Riyadh and Jeddah have endured several flood events that caused extensive economic and human losses [8]. The city of Riyadh having a combined sewer system that is supposed to handle its wastewater as well as its rainwater. This system was unable to absorb the great amounts of water during flash flood events leading to collapsed bridges and loss of life of its citizens. With the city's increasing urbanization rate making the effects of flash floods more severe the city had to diversify its solution strategies in terms of flood protection [9]. As mentioned earlier, the nexus between water, sanitation and energy services highlights the need for intra-departmental communication, and active coordination between different institutions. As one of the key pitfalls of disaster management in the city of Riyadh was having an isolated response system rather than an integrated approach [10].

On the other hand, the city of Riyadh has opted for an alternative approach that capitalizes on the benefits of SDUs to mitigate flash flooding impacts. Initiating the Green Riyadh project which is a part of the country vision towards 2030 [11], the project aims to increase the green footprint of the city as both an increase in quality of life for its citizens and also act as a mitigation measure against floods.
One key element of this project is to build a natural attenuation pond within the urban center to act as a sponge to absorb the water from extreme weather events and then slowly release the water into its conduits [12].

\section{Amman}

Flash floods are nothing new to Jordan's drylands, more witnessed near natural streams delineating to the Dead Sea, the lowest place on Earth. However, they have become alarming as observed more frequent incidents that caused infrastructure damage and lives loss. Similarly, urban areas in Jordan such as Amman, witness frequent floods every year, due to the speedy urbanization that reduced and storm water travel time and overloaded on the storm water conveyance system. The situation is exacerbated by climate change. Although the wet season's temporal and spatial magnitudes are still unpredictable, their existence is evident and increasing over time [13, 14]. This includes the observed high-intensity short duration rainfall storms that are becoming more frequent lately.

Despite the urban expansion, and sensible change in precipitation patterns, the storm water network has not been expanded in terms of capacity. The focus was rather on the periodic maintenance, serving new areas with storm water subnetworks and in protecting low areas from storm water runoffs. An example of this is the downtown of Amman, where Amman municipality uses barriers to mitigate storm water runoff to protect infrastructure and shops, and most importantly, residents of that area. Other measures that are also promoted by the government such as early warnings to flood risks, days or hours before these events. The challenge of the rainy season in Amman is the overload that is caused by illegal connections of rooftops collected water to the storm water network. Amman Municipality and Miahuna have initiated campaigns to raise public awareness to the adverse impact of such practices [15]. However, there is still a room for development. This may lie in projecting the impact of climate change on rainfall patterns and looking for other solutions such as SUDs that may help in managing storm water flows, simultaneously protect the environment and nature.

\section{Recommendations-Lesson Learned}

Extreme weather events due to climate change are a fact , changing the normal life and introducing new challenges for decision-makers, planners and managers. These challenges require innovative solutions to cope with; these innovative solutions must be inclusive and holistic in their approach. Thus, this article discussed the water, sanitation, and energy services nexus; and how it links to water services availability, accessibility, and quality. The nexus highlights the interlinkages at play in the event of flash floods. That communication between the institutions with a mandate of managing them is crucial (named good governance). Especially in the critical hours when flash floods hit mega cities. The paper explored several mitigation strategies applied in developing arid countries, where the magnitude of extreme weather events is accelerating, and their impacts can hinder the developing efforts of 
those countries. It has looked at how countries like Egypt, Jordan and Saudi Arabia are developing context-compatible mitigation measures, and highlighted the pros and cons of these measures in mitigating urban flash floods.

By considering the existing and discussed measures, for developing countries, it is recommended to shift and skip the long path of mitigation through 'grey infrastructure' and adopting natural-based solutions, SDUs or green infrastructure. This paradigm shift would have social, economic, and environmental gains. However, it needs more than top-down decision-making, it requires raising the awareness of citizens on green mitigation and adaptation measures, and the adoption of a participatory risk management approach to improve the community resilience as well as services resilience to climate change impacts. Finally, while floods can be a destructive power to the existing infrastructure causing massive economic loses; it can also be an opportunity to harvest water especially in countries that face water scarcity.

\section{References}

1. Amgad Elmahdi (2019) Road maps for water accounting designing and institutionalizing for sustainable water management in Mena region. Int J Environ Sci Nat Res 22(4).

2. IPCC (2014) Climate Change 2014. In: Pachauri RK, Meyer LA (Eds.), Synthesis Report Contribution of Working Groups I, II and III to the Fifth Assessment Report of the Intergovernmental Panel on Climate Change. IPCC, Geneva, Switzerland, p. 151.

3. WWAP (United Nations World Water Assessment Programme)/UNWater (2018) The united nations world water development report 2018: Nature-Based Solutions for Water. UNESCO, Paris.
4. Pahl-Wostl C (2009) A conceptual framework for analysing adaptive capacity and multi-level learning processes in resource governance regimes. Global Environmental Change 19(3): 354-365.

5. Dorman WJ (2007) The politics of neglect: The Egyptian state in Cairo, 1974-98.

6. https://www.elbalad.news/4209660

7. Mahgoub MESM, Vander Steen NP, Abu-Zeid K, Vairavamoorthy K (2010) Towards sustainability in urban water: a life cycle analysis of the urban water system of Alexandria City, Egypt. Journal of Cleaner Production 18(10-11): 1100-1106.

8. Davies R (2013) Riyadh Flood Defence Plan-Flood List.

9. Sharif HO, Al-Juaidi FH, Al-Othman A, Al-Dousary I, Fadda E, et al. (2016) Flood hazards in an urbanizing watershed in Riyadh, Saudi Arabia. Geomatics, Natural Hazards and Risk 7(2): 702-720.

10. Ledraa TA, Al-Ghamdi AM (2019) Planning and management issues and challenges of flash flooding disasters in Saudi Arabia: The case of Riyadh city. Journal of Architecture and Planning 32(1): 155-171.

11. https://vision2030.gov.sa/

12. https://www.riyadhksp.sa/

13. Salahat M, Al-Qinna M (2015) Rainfall fluctuation for exploring desertification and climate change: New aridity classification. Jordan Journal of Earth and Environmental Sciences 7(1): 27-35.

14. Bos R (2016) Manual on the human rights to safe drinking water and sanitation for practitioners.

15. https://www.almadenahnews.com/article/330350

For possible submissions Click below: 